\title{
Sulforaphane prevents doxorubicin-induced oxidative stress and cell death in rat $\mathrm{H9c2}$ cells
}

\author{
BO LI $^{1 *}$, DO SUNG KIM ${ }^{1 *}$, RAJ KUMAR YADAV ${ }^{1}$, HYUNG RYONG KIM $^{2}$ and HAN JUNG CHAE ${ }^{1}$ \\ ${ }^{1}$ Department of Pharmacology and Institute of Cardiovascular Research, School of Medicine, Chonbuk National University, \\ Jeonju, Chonbuk 561-180; ${ }^{2}$ Department of Dental Pharmacology and Wonkwang Biomaterial Implant Research Institute, \\ School of Dentistry, Wonkwang University, Iksan, Chonbuk 570-749, Republic of Korea
}

Received November 19, 2014; Accepted April 22, 2015

DOI: $10.3892 /$ ijmm.2015.2199

\begin{abstract}
Sulforaphane, a natural isothiocyanate compound found in cruciferous vegetables, has been shown to exert cardioprotective effects during ischemic heart injury. However, the effects of sulforaphane on cardiotoxicity induced by doxorubicin are unknown. Thus, in the present study, H9c2 rat myoblasts were pre-treated with sulforaphane and its effects on cardiotoxicity were then examined. The results revealed that the pre-treatment of $\mathrm{H} 9 \mathrm{c} 2$ rat myoblasts with sulforaphane decreased the apoptotic cell number (as shown by trypan blue exclusion assay) and the expression of pro-apoptotic proteins (Bax, caspase-3 and cytochrome $c$; as shown by western blot analysis and immunostaining), as well as the doxorubicininduced increase in mitochondrial membrane potential (measured by JC-1 assay). Furthermore, sulforaphane increased the mRNA and protein expression of heme oxygenase-1 (HO-1, measured by RT-qPCR), which consequently reduced the levels of reactive oxygen species (ROS, measured using MitoSOX Red reagent) in the mitochondria which were induced by doxorubicin. The cardioprotective effects of sulforaphane were found to be mediated by the activation of the Kelch-like ECH-associated protein 1 (Keap1)/NF-E2-related factor-2 (Nrf2)/antioxidantresponsive element (ARE) pathway, which in turn mediates the
\end{abstract}

Correspondence to: Professor Han Jung Chae, Department of Pharmacology and Institute of Cardiovascular Research, School of Medicine, Chonbuk National University, 567 Baekje-daero, Deokjin-gu, Jeonju, Chonbuk 561-180, Republic of Korea E-mail: hjchae@jbnu.ac.kr

Professor Hyung Ryong Kim, Department of Dental Pharmacology and Wonkwang Biomaterial Implant Research Institute, School of Dentistry, Wonkwang University, 460 Iksandae-ro, Iksan, Chonbuk 570-749, Republic of Korea

E-mail: hrkimdp@wonkwang.ac.kr

*Contributed equally

Key words: doxorubicin, cardiotoxicity, reactive oxygen species, sulforaphane, NF-E2-related factor-2, heme oxygenase-1 induction of HO-1. Taken together, the findings of this study demonstrate that sulforaphane prevents doxorubicin-induced oxidative stress and cell death in $\mathrm{H} 9 \mathrm{c} 2$ cells through the induction of HO-1 expression.

\section{Introduction}

Doxorubicin is a chemotherapeutic agent widely used in the treatment of various types cancers, such as lung, liver, breast, ovarian and bladder cancer (1-6). However, cardiotoxicity is a major side-effect of doxorubicin. Reactive oxygen species (ROS) have been reported as one of the major factors responsible for cardiotoxicity. Doxorubicin is reduced by nicotinamide adenine dinucleotide phosphate-oxidase (NADPH oxidase) to a semi-quinone free radical, which in turn interacts with oxygen to form superoxide, hydroxyl and peroxynitrite free radicals (7). Doxorubicin has been reported to induce oxidative stress and mitochondria-mediated apoptosis in cardiomyocytes, leading to their loss and ultimately contributing to progressive heart failure (8). The administration of antioxidants has been shown to protect cardiac cells from oxidative stress induced by doxorubicin (9-11).

Sulforaphane is a naturally occurring isothiocyanate that is highly abundant in certain cruciferous vegetables (12). L-sulforaphane is the biologically active isomer, whereas $\mathrm{D}, \mathrm{L}-$ sulforaphane is a synthetic racemic analogue of the broccoli constituent, L-sulforaphane (13). Sulforaphane is an antioxidant with cytoprotective effects and anti-carcinogenic properties $(14,15)$ that has been shown to induce the activity of phase II enzymes, such as heme oxygenase-1 (HO-1), quinone reductase, glutathione $\mathrm{S}$-transferase and glutathione reductase (16). Sulforaphane has also been reported to protect the kidneys (17) and brain (18) against ischemic injury through the induction of the activation of transcription factor, NF-E2related factor-2 (Nrf2)-dependent phase II enzymes. Under basal conditions, the cytosolic regulatory protein, Kelch-like ECH-associated protein 1 (Keap1), binds tightly to Nrf2, retaining it in the cytoplasm (19). Phase II enzyme inducers can disrupt the Keap1/Nrf2 complex, resulting in the release of Nrf2 and its subsequent translocation to the nucleus. The induction of the activation of antioxidant enzymes has been reported to involve transcriptional activation through antioxidantresponsive elements (AREs) (19). 
Among the phase II enzymes, HO-1 has attracted significant attention due to its therapeutic effects against neurodegenerative, cardiovascular and hepatic diseases (20-22). Under conditions of oxidative stress, the induction of HO-1 accounts for the majority of heme breakdown, leading to the formation of biliverdin, carbon monoxide $(\mathrm{CO})$ and ferrous iron. In this way, HO-1 mitigates cellular injury by producing molecules with antioxidant and anti-apoptotic effects (20).

The potential cardioprotective effects of sulforaphane have been confirmed by observing reduced ROS production, an increased cell viability (23), and the attenuation of ischemic heart injury through mitochondrial $\mathrm{K}_{\mathrm{ATP}}$ channels and antioxidant pathways (24). However, the effects of sulforaphane on the cardiotoxicity induced by doxorubicin have not been well defined to date. Therefore, the aim of this study was to determine whether sulforaphane protects cells against doxorubicin-induced cardiac cell death. Specifically, we focused on whether the cardioprotective effects of sulforaphane are related to the activation of the Keap1/Nrf2/ARE pathway and the subsequent induction of HO-1.

\section{Materials and methods}

Reagents. Antibodies against cleaved caspase-3 (\#9661) and Bax (\#2772) were purchased from Cell Signaling Technologies (Beverly,MA,USA). Antibodies against cytochrome $c$ (sc-13156), Bcl-2 (sc-7382), HO-1 (sc-10789), histone H3 (sc-8654), Nrf2 (sc-722), Keap1 (sc-365626), Hsp60 (sc-13966) and glyceraldehyde 3-phosphate dehydrogenase (GAPDH) (sc-25778) were purchased from Santa Cruz Biotechnology, Inc. (Santa Cruz, CA, USA). Dulbecco's modified Eagle's medium (DMEM), fetal bovine serum (FBS), trypsin and other tissue culture reagents were obtained from Invitrogen Life Technologies, Inc. (Carlsbad, CA, USA). Hoechst 33258, 5,5',6,6'-tetrachloro1,1'3,3'-tetraethylbenzimidazolylcarbocyanine iodide (JC-1), dihydrorhodamine 123 (DHR123) and MitoSOX Red reagent were purchased from Molecular Probes (Eugene, OR, USA). Doxorubicin, and L-sulforaphane and D,L-sulforaphane were purchased from Sigma-Aldrich (St. Louis, MO, USA). All other chemicals were from Sigma-Aldrich.

Cell culture. The H9c2 rat myoblast cell line (KCLB \#21446, Korean Cell Line Bank, Seoul, Korea) was grown in DMEM supplemented with $10 \%$ FBS and antibiotics $(100 \mu \mathrm{g} / \mathrm{ml}$ streptomycin $/ 100 \mathrm{U} / \mathrm{ml}$ penicillin mix) in a humidified atmosphere at $37^{\circ} \mathrm{C}$ with $5 \% \mathrm{CO}_{2}$.

Determination of cell viability. The $\mathrm{H} 9 \mathrm{c} 2$ cells were passaged and cultured in 24 -well plates at $5 \times 10^{4}$ cells/well for 1 day. The cells were then treated with L-sulforaphane or D,L-sulforaphane for $2 \mathrm{~h}$ prior to the addition of doxorubicin. After $24 \mathrm{~h}$, the cells were assessed by trypan blue exclusion assay using a light microscope to determine the percentage of cell death, as previously described (25). The viable cell ratio was calculated as follows: viable cell ratio $(\%)=($ unstained cell number/total cell number) x 100 .

Morphological detection of apoptotic cells. Hoechst 33258, a fluorescent stain used for labeling DNA, was used to identify the apoptotic H9c2 cells, as described in a previous study (26).
Following treatment, the cells were washed 3 times with phosphate-buffered saline (PBS) and then fixed for 5 min with ice-cold $100 \%$ methanol. After fixation, the cells were stained with Hoechst $33258(10 \mu \mathrm{g} / \mathrm{ml})$ for $10 \mathrm{~min}$ at room temperature in the dark. The cells were then washed with PBS 3 times and examined under a fluorescence microscope (Olympus, Tokyo, Japan). The apoptotic cells were identified by characteristic nuclei condensation, fragmentation and bright staining, while the nuclei from normal cells demonstrated a normal uniform chromatin pattern.

Western blot analysis. Western blot analysis was performed as previously described with some modifications (27). The cells treated for the indicated periods of time were harvested by washing twice with ice-cold PBS on ice. For the preparation of whole-cell lysates, the cells were lysed on ice by the addition of RIPA lysis buffer ( $25 \mathrm{mM}$ Tris- $\mathrm{HCl} \mathrm{pH} 7.4,150 \mathrm{mM} \mathrm{NaCl}$, $1 \%$ sodium deoxycholate, $1 \%$ Triton X-100, 5 mM EDTA, $0.1 \%$ SDS) plus protease inhibitor cocktail and phosphatase inhibitor cocktail (Roche Diagnostics, Mannheim, Germany) directly onto the cells. The cell lysates were incubated for $30 \mathrm{~min}$ on ice, after which they were centrifuged at $10,000 \mathrm{x} \mathrm{g}$ for $20 \mathrm{~min}$ at $4^{\circ} \mathrm{C}$. The supernatants were then collected and used as protein extracts. Protein extracts were added to sample buffer, boiled in a water bath for $5 \mathrm{~min}$ and stored at $-80^{\circ} \mathrm{C}$ until use. Protein extracts $(30 \mu \mathrm{g})$ were run on polyacrylamide gels and transferred onto PVDF membranes for 40 min at $15 \mathrm{~V}$ using a semi-dry transfer system (Bio-Rad, Hercules, CA, USA). The membranes were blocked with $5 \%$ non-fat dry milk in $0.05 \%$ Tween-20/Tris-buffered saline (T-TBS) for $60 \mathrm{~min}$ at room temperature. The blots were then probed overnight at $4^{\circ} \mathrm{C}$ with the relevant primary antibodies, washed and probed again with species-specific secondary antibodies coupled to horseradish peroxidase (Santa Cruz Biotechnology, Inc.). Chemiluminescence reagents (GE Healthcare, Piscataway, NJ, USA) were added for blot detection. Immunoreactive bands were visualized using a LAS-3000 imaging system (Fujifilm, Tokyo, Japan). Band intensities were measured and quantified using ImageJ software as described by Luke Miller (http:// lukemiller.org/journal/2007/08/quantifying-western-blotswithout.html).

Detection of cytochrome $c$ and Bax by western blot analysis. To determine the subcellular localization of cytochrome $c$ and Bax, the cells were fractionated using digitonin, as previously described (28). Briefly, the cells were suspended in ice-cold plasma membrane permeabilization buffer (200 $\mu \mathrm{g} /$ $\mathrm{ml}$ digitonin, $80 \mathrm{mM} \mathrm{KCl}$ in PBS). Following a 5-min incubation on ice, the cells were centrifuged at $800 \mathrm{x}$ g for $5 \mathrm{~min}$ at $4^{\circ} \mathrm{C}$ and the soluble extract was taken as the cytosolic fraction. The insoluble pellet was further resuspended in ice-cold cell lysis buffer and incubated on ice for $10 \mathrm{~min}$. Following centrifugation at $10,000 \mathrm{x}$ g for $10 \mathrm{~min}$ at $4^{\circ} \mathrm{C}$, the resulting supernatant was taken as the membrane-bound organellar fraction enriched with mitochondria. These two fractions were analyzed by western blot analysis using antibodies specific for cytochrome $c$, Bax, Hsp60 and GAPDH.

Immunostaining for cytochrome $c$ and Bax. Protocols for the immunofluorescence staining for cytochrome $c$ and Bax were 
used as previously described with some modifications (29). The H9c2 cells were grown on coverglass-bottom dishes and treated with the indicated agents. The cells were then fixed with ice-cold methanol and permeabilized with PBST (PBS containing $0.25 \%$ Triton X-100). Following a 30-min incubation in blocking buffer (1\% BSA in PBST), the cells were incubated with rabbit anti-Bax antibody (1:300) overnight at $4^{\circ} \mathrm{C}$. Subsequently, the cells were washed twice and stained with FITC-conjugated goat anti-rabbit secondary antibody (1:300; A24532; Thermo Fisher Scientific, Rockford, IL, USA) for $1 \mathrm{~h}$. The cells were then incubated with mouse anti-cytochrome $c$ antibody (1:300) for $1 \mathrm{~h}$ and then stained with TRITC-conjugated goat anti-mouse secondary antibody (1:600; ab6786; Abcam, Cambridge, UK) for $1 \mathrm{~h}$. Finally, the cells were mounted using Vectashield mounting medium containing DAPI, and signals were examined under a fluorescence microscope using FITC, TRITC and DAPI channels.

JC-1 mitochondrial membrane potential $(\Delta \Psi m)$ assay. $\Delta \Psi \mathrm{m}$ was determined by flow cytometry using the J-aggregate forming lipophilic cationic probe, JC-1, according to the manufacturer's instructions (Molecular Probes). JC-1 stains the mitochondria in cells with a high $\Delta \Psi \mathrm{m}$ by forming red fluorescence J-aggregates (30), whereas in cells with depolarized mitochondria, JC-1 is present as a green fluorescent monomer. In this way, mitochondrial depolarization can be determined by a decreased ratio of red-to-green fluorescence intensity. The cells were grown in glass-bottom dishes (SPL Life Sciences Co., Ltd., Pochoen, Korea). Following treatment, JC-1 was dissolved in dimethyl sulfoxide $(1 \mathrm{mg} / \mathrm{ml})$, diluted to a final concentration of $1 \mu \mathrm{g} / \mathrm{ml}$ in serum-free medium and then added to the cells followed by incubation for $10 \mathrm{~min}$ at $37^{\circ} \mathrm{C}$; the cells were then washed twice with PBS. Subsequently, the cells were incubated in $1 \mathrm{ml}$ of culture medium and analyzed under a fluorescence microscope (Olympus).

DHR123. DHR123 is a cell-permeable fluorogenic probe and an indicator of peroxynitrite levels $(31,32)$. Specifically, DHR123 is oxidized by peroxynitrite to cationic rhodamine 123, which localizes in the mitochondria and exhibits green fluorescence (33). Neither nitric oxide, superoxide, nor hydrogen peroxide alone appear to oxidize DHR (34). In order to determine the level of mitochondrial peroxynitrite by fluorescence microscopy, the cells were grown in glass-bottom dishes (SPL Life Sciences Co., Ltd.). Following treatment, DHR123 was dissolved in dimethyl sulfoxide $(5 \mathrm{mM})$ and diluted to $1.25 \mu \mathrm{M}$ in serum-free medium. The cells were treated with DHR123 for $30 \mathrm{~min}$ at $37^{\circ} \mathrm{C}$ and then washed twice with PBS. Subsequently, the cells were incubated in $1 \mathrm{ml}$ of culture medium and analyzed under a fluorescence microscope (Olympus).

MitoSOX. MitoSOX Red is a novel fluorogenic dye that serves as an indicator of mitochondrial superoxide levels in live cells $(35,36)$. MitoSOX Red reagent is live-cell permeant and is rapidly and selectively targeted to the mitochondria. Once in the mitochondria, MitoSOX Red reagent is oxidized by superoxide and emits red fluorescence. In order to determine the levels of mitochondrial superoxide by fluorescence microscopy, the cells were grown in glass-bottom dishes (SPL Life Sciences Co., Ltd.).
Following treatment, MitoSOX reagent was dissolved in dimethyl sulfoxide $(5 \mathrm{mM})$, diluted to $5 \mu \mathrm{M}$ in serum-free medium, and was then added to the cells followed by incubation for $10 \mathrm{~min}$ at $37^{\circ} \mathrm{C}$; the cells were then washed twice with PBS. Subsequently, the cells were incubated in $1 \mathrm{ml}$ of culture medium and analyzed under a fluorescence microscope (Olympus).

Detection of Nrf 2 and Keapl by western blot analysis. Nuclear and cytoplasmic extracts of $\mathrm{H} 9 \mathrm{c} 2$ cells were prepared using NE-PER nuclear and cytoplasmic extraction reagent (Pierce Biotechnology, Rockford, IL, USA) as recommended by the manufacturer. The two fractions were analyzed by western blot analysis with antibodies specific to Nrf2 and Keap1.

Immunostaining for Nrf2 and Keapl. The H9c2 cells were grown on coverglass-bottom dishes and treated with the indicated agents. The cells were then fixed with ice-cold methanol and permeabilized with PBST (PBS containing $0.25 \%$ Triton $\mathrm{X}-100)$. Following incubation for $30 \mathrm{~min}$ in blocking buffer (1\% BSA in PBST), the cells were incubated with rabbit anti-Nrf2 antibody (1:400) overnight at $4^{\circ} \mathrm{C}$. The cells were then washed twice and stained with FITC-conjugated goat anti-rabbit secondary antibody (1:400) for $1 \mathrm{~h}$. Subsequently, the cells were incubated with mouse anti-Keap1 antibody (1:100) for $1 \mathrm{~h}$ and then stained with TRITC-conjugated goat anti-mouse secondary antibody (1:200) for $1 \mathrm{~h}$. Finally, the cells were mounted using Vectashield mounting medium with DAPI. Signals were examined by fluorescence microscopy using the FITC, TRITC and DAPI channels.

Reverse transcription-quantitative PCR (RT-qPCR). Total RNA was extracted from the H9c2 cells using TRIzol reagent (Invitrogen Life Technologies). The ethanol-precipitated RNA fraction (500 ng) was reverse transcribed using the PrimeScript $^{\text {TM }}$ RT reagent kit (RR037A; Takara, Shiga, Japan) according to the manufacturer's protocol. The primers used for PCR were as follows: 5'-AGAGTTTCCGCCTCCAACCA-3' and 5'-CGGGACTGGGCTAGTTCAGG-3' for rat HO-1 and 5'-CAGTCAAGGCTGAGAATGG-3' and 5'-CGACATACT CAGCACCAGC-3' for rat GAPDH, as described in a previous study (37). Relative gene expression was determined by quantitative (real-time) PCR (qPCR) using an Applied Biosystems 7900HT Fast Real-Time PCR system (Applied Biosystems, Foster City, CA, USA) according to the instructions provided by the manufacturer.

ARE luciferase activity assay. The cells were transfected with an ARE promoter luciferase reporter plasmid for $24 \mathrm{~h}$ and then treated with doxorubicin in the absence or presence of L-sulforaphane or D,L-sulforaphane for various periods of time. Cell lysates were prepared and assayed for luciferase activity using the Luciferase Assay System (Promega, Madison, WI, USA) according to the manufacturer's instructions. Changes in luciferase activity with respect to the controls (untreated cells) were then calculated.

Statistical analysis. All data are presented as the means \pm SEM. A two-tailed Student's t-test was applied to examine the statistical significance of differences between groups. Origin 8.0 software (OriginLab Corp., Northampton, MA, USA) was 

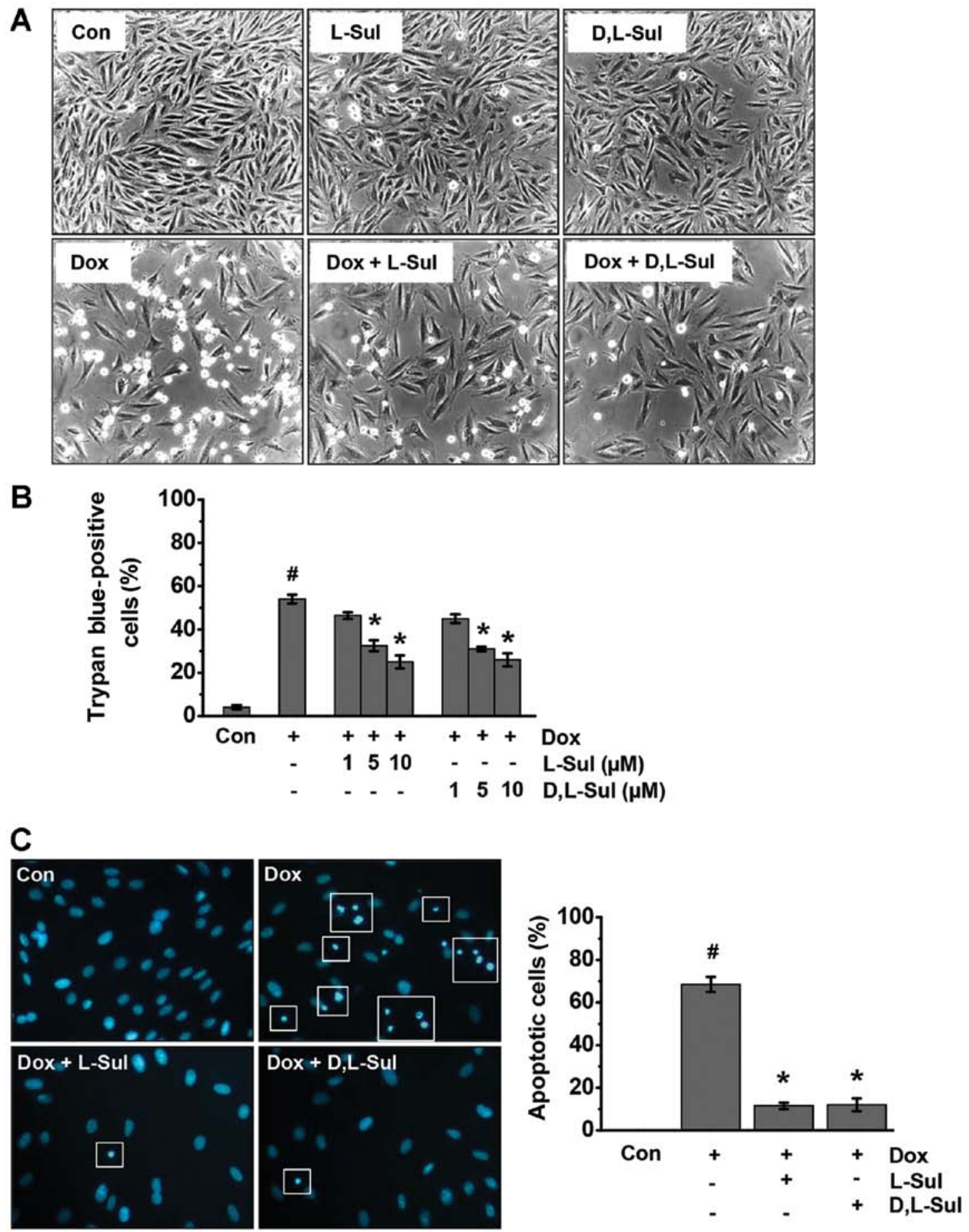

Figure 1. L-sulforaphane (L-Sul) and D,L-sulforaphane (D,L-Sul) protect against doxorubicin (Dox)-induced cell death. (A) H9c2 cells were stimulated with $1 \mu \mathrm{M}$ Dox or pre-treated with $10 \mu \mathrm{M} \mathrm{L}$-Sul or D,L-Sul for $2 \mathrm{~h}$ and then treated with $1 \mu \mathrm{M}$ Dox for $24 \mathrm{~h}$. The effects of L-Sul or D,L-Sul on Dox-induced cell death and morphological alterations in the $\mathrm{H} 9 \mathrm{c} 2$ cells were observed under a light microscope. (B) Determination of H9c2 cell viability by trypan blue exclusion assay. ${ }^{~} \mathrm{P}<0.05$ vs. controls; ${ }^{*} \mathrm{P}<0.05$ vs. Dox-treated group. (C) Morphological apoptosis was determined by Hoechst 33258 staining under a fluorescence microscope (left panel). Bar graph showing the quantification of apoptotic cells as a percentage of total cells (right panel). White sqaure boxes indicate apoptotic cells. " $\mathrm{P}<0.05$ vs. controls; ${ }^{*} \mathrm{P}<0.05$ vs. Dox-treated group.

used for statistical calculations. Values of $\mathrm{P}<0.05$ were considered to indicate statistically significant differences.

\section{Results}

L-sulforaphane and D, L-sulforaphane protect $H 9 c 2$ myoblasts against doxorubicin-induced cell death. The $\mathrm{H} 9 \mathrm{c} 2$ cells were exposed to doxorubicin and cell viability was examined after $24 \mathrm{~h}$ under a light microscope and by trypan blue exclusion assay. Based on the results obtained by light microscopy, treatment of the $\mathrm{H} 9 \mathrm{c} 2$ cells with doxorubicin induced morphological changes, including rounding up and detachment. Treatment with L-sulforaphane and D,L-sulforaphane clearly protected the $\mathrm{H} 9 \mathrm{c} 2$ cells against doxorubicin-induced 
cell death (Fig. 1A). In addition, treatment with either L-sulforaphane or D,L-sulforaphane alone was not toxic to the H9c2 cells. Analysis of trypan blue dye uptake also revealed that both L-sulforaphane and D,L-sulforaphane increased cell viability in a dose-dependent manner (Fig. 1B). The results of the analysis of apoptotic cells using Hoechst 33258 staining are shown on the left panel of Fig. 1C. Following treatment with doxorubicin, the $\mathrm{H} 9 \mathrm{c} 2$ cells exhibited numerous brightly condensed and broken fluorescent nuclei. Conversely, the number of apoptotic cells treated with doxorubicin was significantly decreased in the cells pre-treated with L-sulforaphane or D,L-sulforaphane. The results of the quantification of apoptotic cells are shown on the right panel of Fig. 1C.

L-sulforaphane and D,L-sulforaphane protect $H 9 c 2$ myoblasts against the doxorubicin-induced translocation of Bax to the mitochondria and the release of cytochrome $c$. We then evaluated the effects of L-sulforaphane and D,L-sulforaphane on translocation of Bax to the mitochondria and the subsequent release of cytochrome $c$ following treatment with doxorubicin using cellular fractionation and western blot analysis. Kinetic analysis of the appearance of the main signs of apoptosis in the doxorubicin-treated cells revealed the rapid release of mitochondrial cytochrome $c$ into the cytosol of H9c2 cells within $4 \mathrm{~h}$ of treatment (Fig. 2A). The presence of L-sulforaphane and D,L-sulforaphane prevented the release of cytochrome $c$ into the cytosol in comparison to the group treated with doxorubicin alone (Fig. 2B). Similarly, in the cells treated with doxorubicin alone, we observed a time-dependent increase in the translocation of Bax to the mitochondria and a concomitant decrease in cytosolic Bax levels (Fig. 2A). Pre-treatment with L-sulforaphane and D,L-sulforaphane prevented the translocation of Bax into the cytosol compared to the cells treated with doxorubicin alone (Fig. 2B). We also investigated the subcellular distribution of Bax and cytochrome $c$ in the H9c2 cells by dual immunofluorescence staining of Bax and cytochrome $c$. The control cells displayed a cytosolic distribution pattern of Bax and a punctate pattern of cytochrome $c$ immunostaining (Fig. 2C). During apoptosis induced by doxorubicin, Bax translocated to the mitochondria and displayed a punctate pattern. The Bax-positive cells displayed a diffuse cytosolic pattern of cytochrome $c$ staining, as well as a condensed and shrunken nucleus as assessed by Hoechst 33258 staining (Fig. 1C). Consistent with the results from western blot analysis (Fig. 2B), pre-treatment with L-sulforaphane and $\mathrm{D}, \mathrm{L}-$ sulforaphane prevented the translocation of Bax to the mitochondria and the release of cytochrome $c$ (Fig. 2C).

$L$-sulforaphane and D,L-sulforaphane prevent the doxorubicin-induced activation of caspase-3 and protect cells against doxorubicin-induced changes in $\Delta \Psi m$. Doxorubicin was found to induce time-dependent cell apoptosis in the $\mathrm{H} 9 \mathrm{c} 2$ cells. Treatment with doxorubicin significantly increased the levels of cleaved caspase- 3 at $8 \mathrm{~h}$; these levels increased further in a time-dependent manner (Fig. 3A). As shown in Fig. 3B, both L-sulforaphane and D,L-sulforaphane attenuated the doxorubicin-induced increase in the levels of cleaved caspase-3. $\Delta \Psi \mathrm{m}$ is one of the key events during apoptosis (38). Mitochondrial permeability transition has been implicated in the collapse of $\Delta \Psi \mathrm{m}$. To monitor $\Delta \Psi \mathrm{m}$, we used the JC-1 dye and measured the emission ratio at 590 to $527 \mathrm{~nm}$. As shown in Fig. 3C, the control cells exhibited mostly brightly stained mitochondria emitting red fluorescence, whereas the H9c2 cells treated with doxorubicin produced green fluorescence indicative of mitochondrial depolarization and the collapse of $\Delta \Psi \mathrm{m}$. We observed an approximately $80 \%$ loss in $\Delta \Psi \mathrm{m}$ in the cells treated with doxorubicin alone compared with the control cells (Fig. 3D). Conversely, the cells pre-treated with either L-sulforaphane or D,L-sulforaphane exhibited a significant preservation of red fluorescence compared with the cells treated with doxorubicin alone (Fig. 3C and D).

L-sulforaphane and D,L-sulforaphane reduce the doxorubicin-induced generation of mitochondrial ROS in H9c2 cells. ROS are involved in doxorubicin-induced cell apoptosis (39-41). Previous studies have suggested that cardiomyocyte mitochondria are important intracellular targets of ROS during doxorubicin-induced cardiotoxicity. Superoxide and peroxynitrite are the major ROS induced by doxorubicin $(42,43)$. Thus, in the present study, we evaluated whether L-sulforaphane and D,L-sulforaphane influence the generation of doxorubicin-induced ROS. The cells were analyzed for mitochondrial superoxide generation by fluorescence microscopy using the mitochondria-targeted dye, dihydroethidium (MitoSOX Red), as a probe (Fig. 4A). Our results indicated that doxorubicin increased mitochondrial superoxide generation compared to the untreated control cells. Conversely, the doxorubicin-induced MitoSOX fluorescence intensity was attenuated by pre-treatment with L-sulforaphane and D,L-sulforaphane (Fig. 4A). We also investigated the generation of mitochondrial peroxynitrite using the dye, DHR123, as a probe. As shown in Fig. 4B, the doxorubicin-induced DHR123 fluorescence was attenuated by pre-treatment wtih L-sulforaphane and D,L-sulforaphane. Taken together, these results suggest that both L-sulforaphane and D,L-sulforaphane protect $\mathrm{H} 9 \mathrm{c} 2$ cells against doxorubicin-induced apoptosis by preventing doxorubicin-induced mitochondrial ROS generation.

L-sulforaphane and D,L-sulforaphane activate HO-1 through AREs in H9c2 cells. L-sulforaphane and D,L-sulforaphane protected the H9c2 cells from doxorubicin-induced oxidative insults (Fig. 4). This protective action of sulforaphane may be related to the induction of HO-1, which, along with other phase II enzymes, serves as a defense system against oxidative stress $(44,45)$. Using RT-qPCR, we found that pre-treatment with L-sulforaphane and D,L-sulforaphane induced HO-1 mRNA expression in a dose-dependent manner(Fig. 5A panel a). In addition, pre-treatment with L-sulforaphane and D,L-sulforaphane reversed the decrease in HO-1 mRNA expression observed in the cells treated with doxorubicin alone (Fig. 5A panel b). We then measured HO-1 protein expression levels by western blot analysis. Consistent with our mRNA data, pre-treatment with L-sulforaphane and D,L-sulforaphane induced a significant increase in HO-1 protein expression (Fig. 5B). Furthermore, HO-1 protein expression was higher in the cells pre-treated with L-sulforaphane and D,L-sulforaphane before the addition of doxorubicin compared with cells treated only with doxorubicin. We also found that L-sulforaphane and D,L-sulforaphane stimulated ARE-dependent transcriptional activity in a 
A

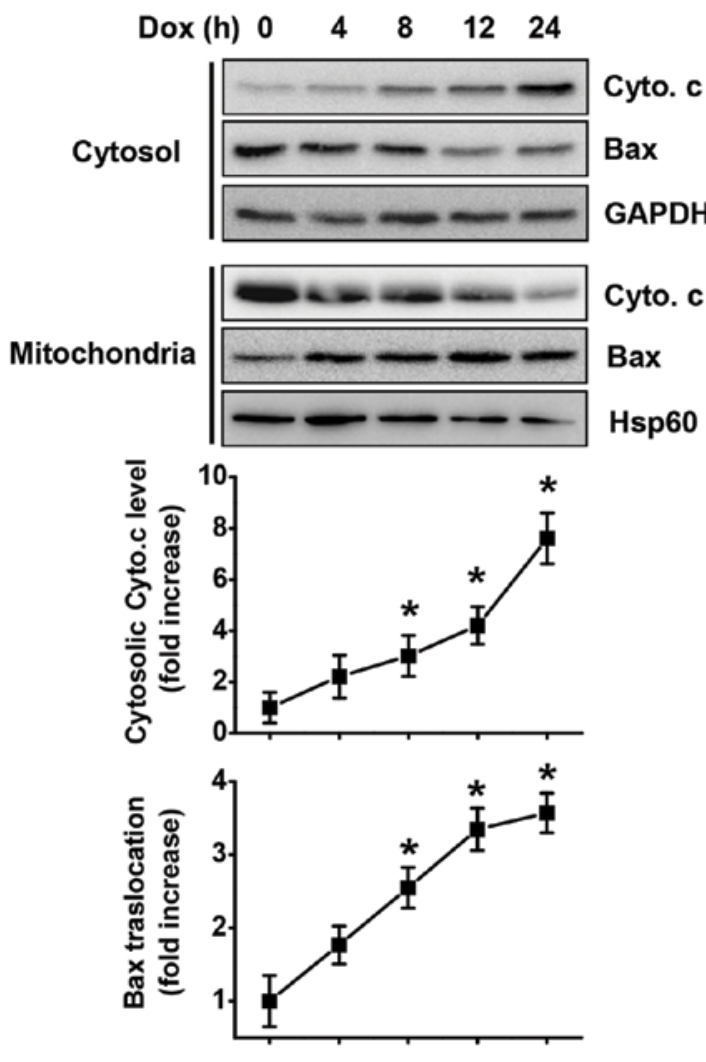

B
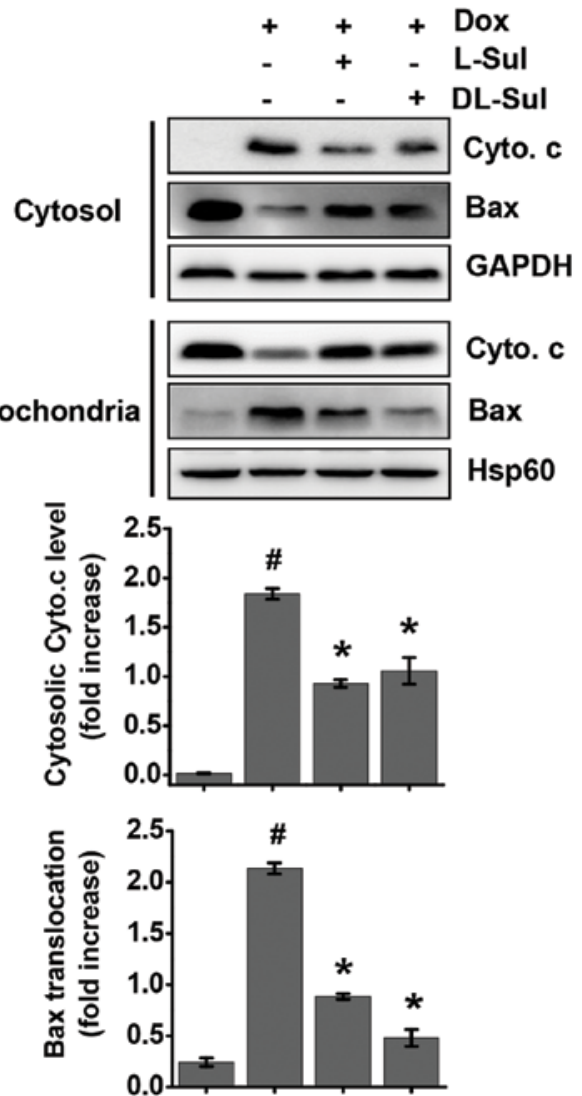

C

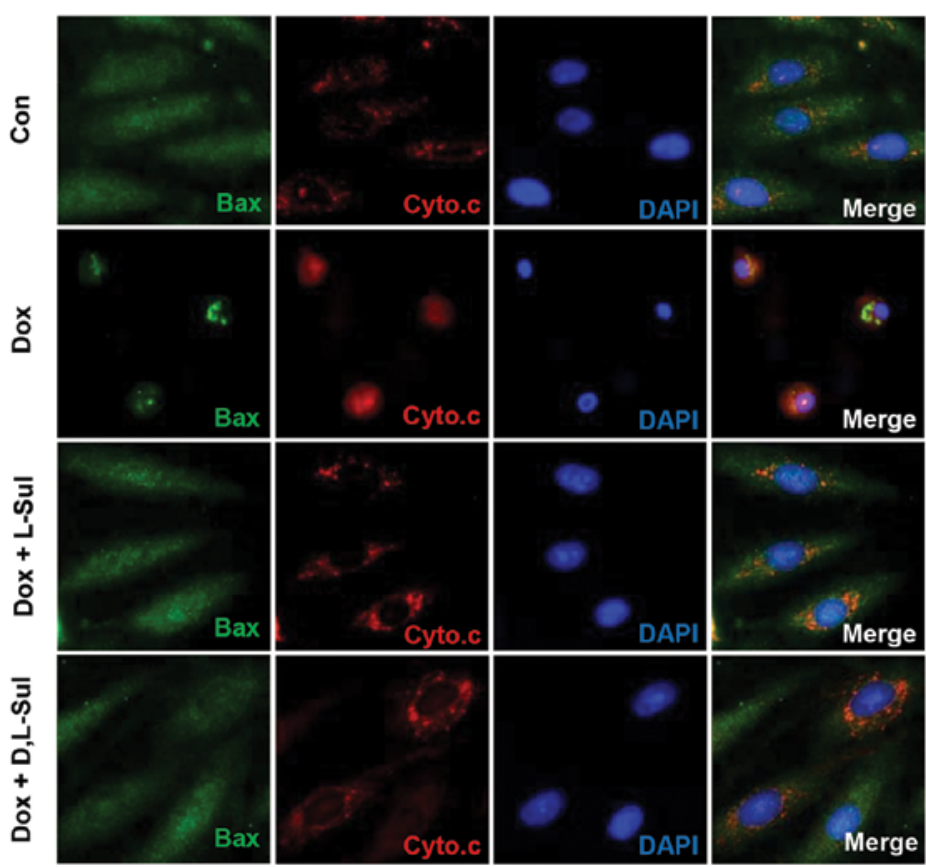

Figure 2. L-sulforaphane (L-Sul) and D,L-sulforaphane (D,L-Sul) prevent the doxorubicin (Dox)-induced release of cytochrome $c$ and Bax activation. (A) H9c2 cells were treated with $1 \mu \mathrm{M}$ Dox for the indicated periods of time. Cells were processed into cytosolic and mitochondrial fractions and subjected to western blot analysis of Bax and cytochrome $c$ (upper panel). The lower panel shows the results of densitometric analysis. " $\mathrm{P}<0.05$ vs. controls. (B) H9c2 cells were pre-treated with $10 \mu \mathrm{M} \mathrm{L}$-Sul or D,L-Sul for $2 \mathrm{~h}$, and then treated with $1 \mu \mathrm{M}$ Dox for $24 \mathrm{~h}$. Cells were then processed into cytosolic and mitochondrial fractions and subjected to western blot analysis of Bax and cytochrome $c$ (upper panel). The lower panel shows the results of densitometric analysis. " $\mathrm{P}<0.05 \mathrm{vs}$. controls; ${ }^{*} \mathrm{P}<0.05$ vs. Dox-treated group (C) H9c2 cells were stimulated with $1 \mu \mathrm{M}$ Dox or pre-treated with $10 \mu \mathrm{M} \mathrm{L}-$ Sul or D,L-Sul for $2 \mathrm{~h}$, and then treated with $1 \mu \mathrm{M}$ Dox for $24 \mathrm{~h}$. Cells were double-immunostained for Bax and cytochrome $c$ and the nuclei were visualized by DAPI staining. Cyto. c, cytochrome $c$.

dose-dependent manner (Fig. 5C panel a). Similarly, pretreatment with L-sulforaphane and D,L-sulforaphane increased
ARE-dependent transcriptional activity compared to the cells treated with doxorubicin alone (Fig. 5C panel b). Taken 
A

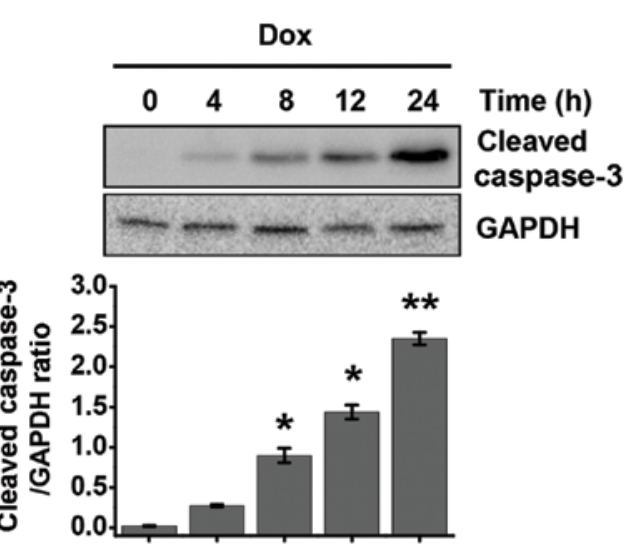

B

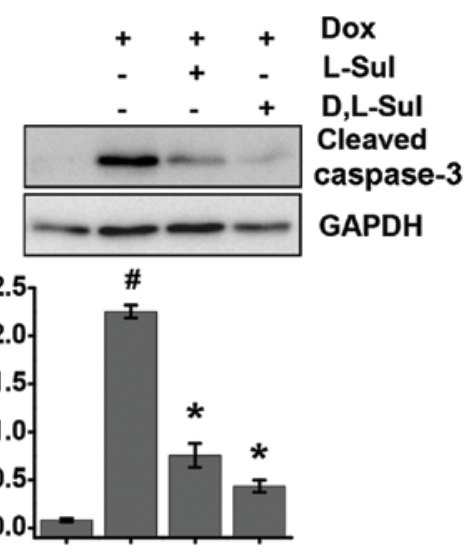

C

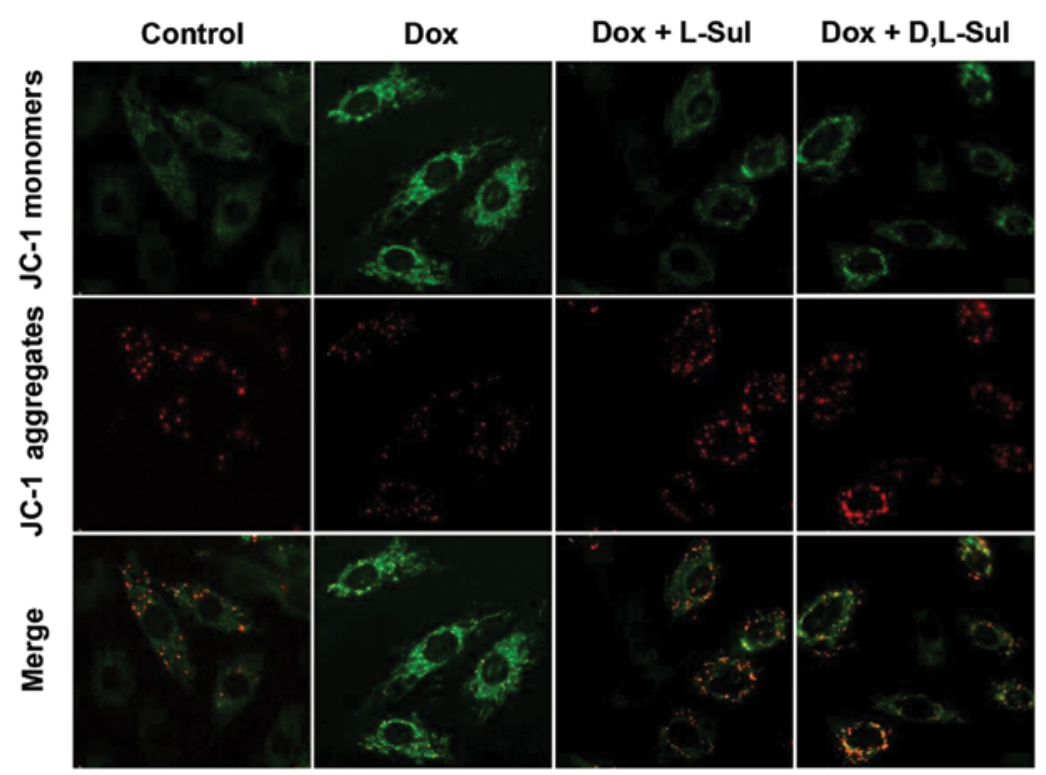

D

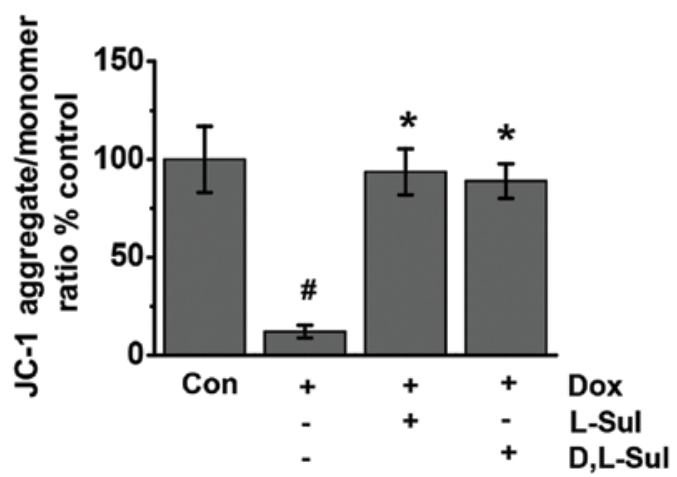

Figure 3. L-sulforaphane (L-Sul) and D,L-sulforaphane (D,L-Sul) prevent the doxorubicin (Dox)-induced activation of caspase-3 and protect against Dox-induced changes in mitochondrial transmembrane potential. (A) H9c2 cells were treated with $1 \mu \mathrm{M}$ Dox for the indicated periods of time. Cells were lysed and examined for the levels of cleaved caspase- 3 by western blot analysis (upper panel). The relative cleaved caspase- 3 protein level was normalized to the $\beta$-actin level (lower panel). ${ }^{\mathrm{P}}<0.05$ and ${ }^{* * *} \mathrm{P}<0.001$ vs. controls. (B) H9c2 cells were pre-treated with $10 \mu \mathrm{M} \mathrm{L}-\mathrm{Sul}$ or D,L-Sul for $2 \mathrm{~h}$, and then treated with $1 \mu \mathrm{M}$ Dox for $24 \mathrm{~h}$. Cells were lysed and examined for the levels of cleaved caspase-3 by western blot analysis (upper panel). Relative cleaved caspase- 3 protein levels were normalized to $\beta$-actin level (lower panel). ${ }^{*} \mathrm{P}<0.05$ vs. controls; ${ }^{*} \mathrm{P}<0.05$ vs. Dox-treated group. (C) H9c2 cells were stimulated with $1 \mu \mathrm{M}$ Dox or pre-treated with $10 \mu \mathrm{M}$ L-Sul or D,L-Sul for $2 \mathrm{~h}$, and then treated with $1 \mu \mathrm{M}$ Dox for $24 \mathrm{~h}$. Mitochondrial membrane potential was detected by JC-1 fluorescence staining. Specifically, the cells were stained with JC-1 and examined under a fluorescence microscope for the detection of red JC-1 aggregates (590 nm emission) or green JC-1 monomers (527 nm emission). Typical images are shown at x600 magnification. (D) Quantification of data in (C). ${ }^{~} \mathrm{P}<0.05$ vs. controls; ${ }^{*} \mathrm{P}<0.05$ vs. Dox-treated group.

together, these results demonstrate that sulforaphane induces HO-1 mRNA and protein expression by activating AREs.
Activation of the Keapl/Nrf2 pathway by L-sulforaphane and $D, L$-sulforaphane in $H 9 c 2$ cells. We then investigated the 

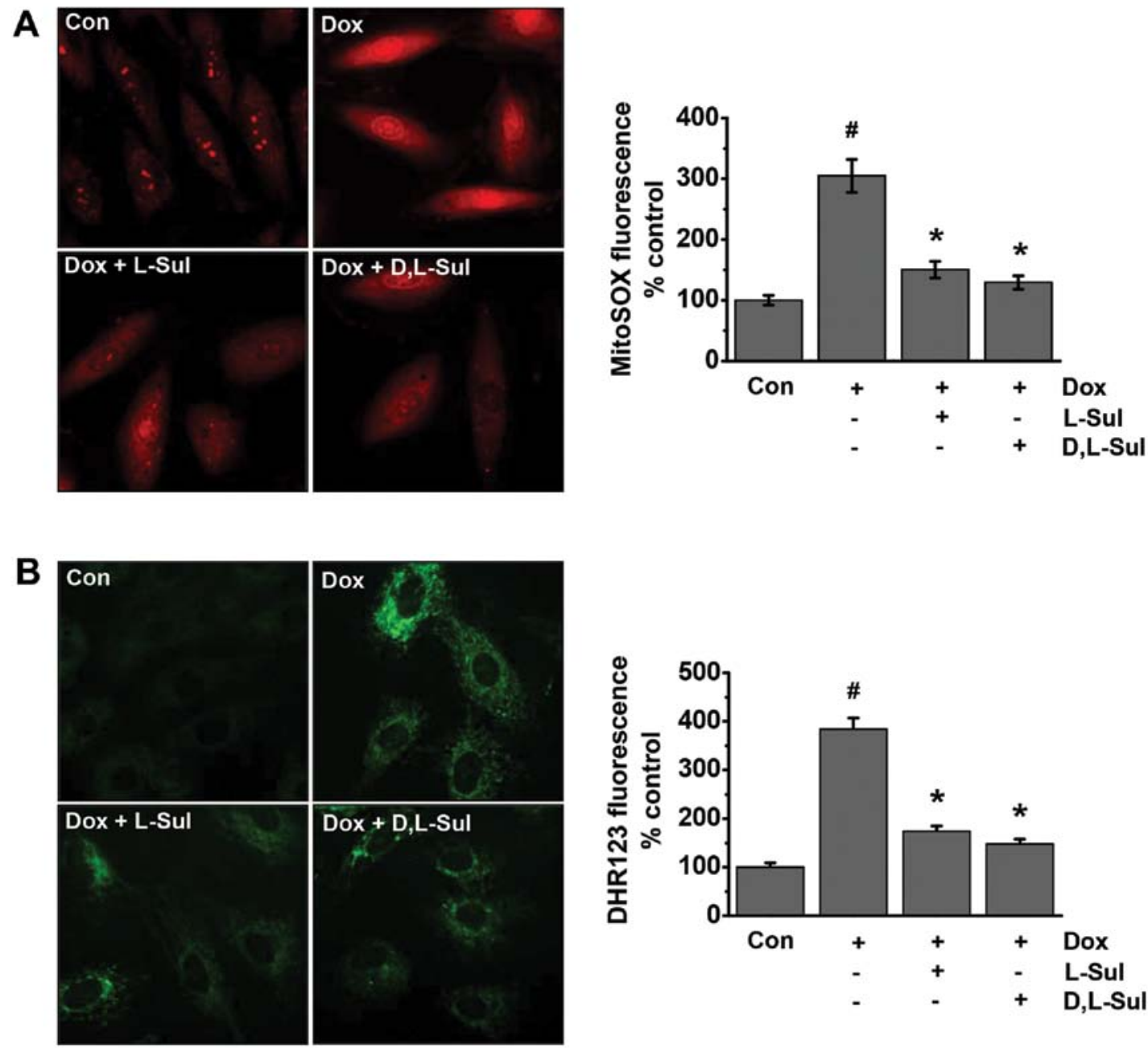

Figure 4. L-sulforaphane (L-Sul) and D,L-sulforaphane (D,L-Sul) reduce the doxorubicin (Dox)-induced generation of mitochondrial reactive oxygen species (ROS) in H9c2 cells. (A) H9c2 cells were treated with $1 \mu \mathrm{M}$ doxorubicin or pre-treated with $10 \mu \mathrm{M} \mathrm{L}-$ Sul or D,L-Sul for $2 \mathrm{~h}$, and then treated with $1 \mu \mathrm{M}$ Dox for $24 \mathrm{~h}$. Cells were then analyzed for mitochondrial superoxide generation by fluorescence microscopy using MitoSOX Red. Representative micrographs are shown on the left panel, and quantification plots are shown on the right panel. Results were calculated as a percentage of control in fluorescence intensity compared with the control group. Plots are the means $\pm \mathrm{SE}(\mathrm{n}=3) .{ }^{~}{ }^{\mathrm{P}}<0.05$ vs. controls; ${ }^{*} \mathrm{P}<0.05$ vs. Dox-treated group. (B) H9c2 cells were treated with $1 \mu \mathrm{M}$ Dox or pre-treated with $10 \mu \mathrm{M} \mathrm{L}$-Sul or D,L-Sul for $2 \mathrm{~h}$, and then treated with $1 \mu \mathrm{M}$ Dox for $24 \mathrm{~h}$. Cells were then analyzed for mitochondrial peroxynitrite generation by fluorescence microscopy using DHR123. Representative micrographs are shown on the left panel, and quantification plots are shown on the right panel. Results are calculated as a percentage of control in fluorescence intensity compared with the control group. Plots are the means $\pm \mathrm{SE}(\mathrm{n}=3)$. ${ }^{\#} \mathrm{P}<0.05$ vs. controls; ${ }^{*} \mathrm{P}<0.05$ vs. Dox-treated group.

activation status of $\mathrm{Nrf} 2$ in the $\mathrm{H} 9 \mathrm{c} 2$ cells by assessing the nuclear translocation of Nrf2 by western blot analysis of the cytosolic and nuclear fractions and by immunofluorescence staining of Nrf2 and Keap1 (Fig. 6). Immunofluorescence staining and confocal microscopy revealed that Nrf2 and Keap1 were predominantly localized in the cytoplasm under basal conditions. In the doxorubicin-treated positive cells, Nrf2 was almost completely absent in the nuclear fraction. Conversely, the nuclear Nrf2 content was increased in the presence of L-sulforaphane and D,L-sulforaphane, whereas Keap1 remained localized in the cytoplasm (Fig. 6A). Similarly, western blot analysis revealed that $\mathrm{Nrf} 2$ expression induced by L-sulforaphane and D,L-sulforaphane was present at much higher levels in the nucleus than in the cytoplasmic fraction (Fig. 6B). Taken together, these results demonstrate that L-sulforaphane and D,L-sulforaphane activate the Keap1/Nrf2 pathway in $\mathrm{H} 9 \mathrm{c} 2$ cells.

\section{Discussion}

Recent evidence suggests a critical role of ROS in doxorubicininduced cardiotoxicity, leading to left ventricular pathological hypertrophy and ultimately, heart failure (46). Therefore, the induction of the activation endogenous antioxidants and phase II enzymes by dietary means may be a promising cardioprotective strategy. In this study, we found that sulforaphane protected $\mathrm{H} 9 \mathrm{c} 2$ cells against cell death induced by doxorubicin. Sulforaphane induced Nrf2-activated HO-1 expression, which consequently reduced ROS levels induced by doxorubicin. In this study, we used H9c2 cells as a model for in vitro studies of doxorubicin-induced cardiotoxicity. The H9c2 cell line was originally derived from embryonic rat ventricular tissue (47), which is important to note, as cardiac hypertrophy resulting from hypertension occurs primarily in the ventricular muscle of the heart. Although H9c2 cells have lost their ability to spon- 

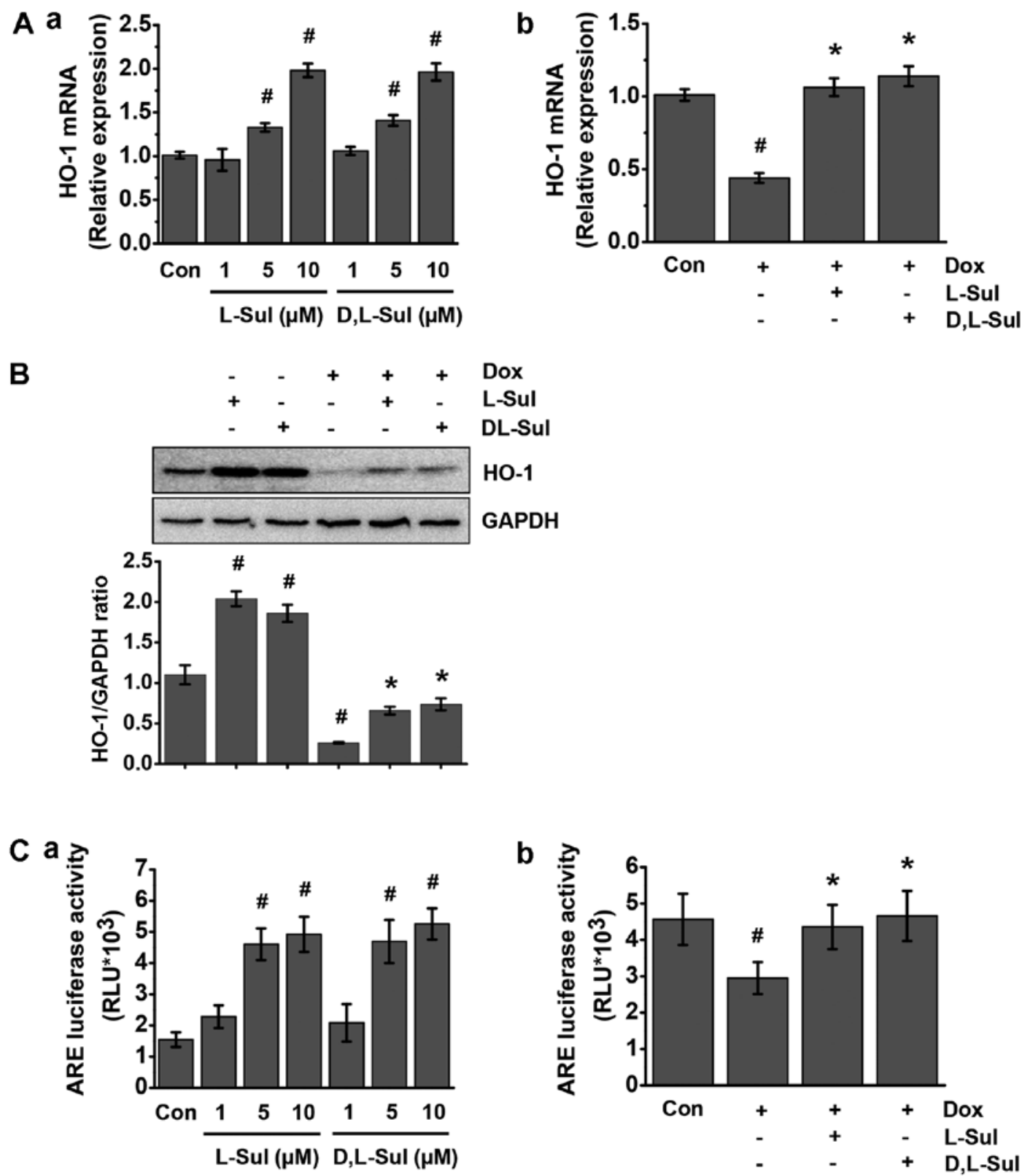

Figure 5. L-sulforaphane (L-Sul) and D,L-sulforaphane (D,L-Sul) activate heme oxygenase-1 (HO-1) through antioxidant-responsive elements (AREs) in H9c2 cells. (A. panel a) H9c2 cells were treated with $10 \mu \mathrm{M} \mathrm{L}$-Sul or D,L-Sul for $24 \mathrm{~h}$. (Panel b) H9c2 cells were treated with $1 \mu \mathrm{M}$ doxorubicin (Dox) or pre-treated with $10 \mu \mathrm{M} \mathrm{L}$-Sul or D,L-Sul for $2 \mathrm{~h}$, and then treated with $1 \mu \mathrm{M}$ Dox for $24 \mathrm{~h}$. HO-1 mRNA levels were measured by RT-qPCR. ${ }^{*} \mathrm{P}<0.05 \mathrm{vs}$. controls; " $\mathrm{P}<0.05$ vs. Dox-treated group. (B) Protein expression of HO-1 and glyceraldehyde 3-phosphate dehydrogenase (GAPDH) was measured by western blot analysis. Densitometric analysis is shown on the lower panel. ${ }^{~} \mathrm{P}<0.05$ vs. controls; ${ }^{*} \mathrm{P}<0.05$ vs. Dox-treated. (C, panel a) H9c2 cells were treated with $10 \mu \mathrm{M}$ L-Sul or D,L-Sul for $24 \mathrm{~h}$. (Panel b) H9c2 cells were treated with $1 \mu \mathrm{M}$ Dox or pre-treated with $10 \mu \mathrm{M} \mathrm{L}-$ Sul or D,L-Sul for $2 \mathrm{~h}$, and then treated with $1 \mu \mathrm{M}$ Dox for $24 \mathrm{~h}$. ARE luciferase activity was measured. ${ }^{\#} \mathrm{P}<0.05$ vs. controls; ${ }^{*} \mathrm{P}<0.05$ vs. Dox-treated group.

taneously contract, they still show many similarities to primary cardiomyocytes $(48,49)$. Indeed, previous studies, using a cell culture approach have investigated doxorubicin-induced cardiac hypertrophy with rat $\mathrm{H} 9 \mathrm{c} 2$ ventricular myocardial cells as a model $(50,51)$.

The data from the present study demonstrated that doxorubicin activated apoptotic signaling as indicated by a significant increase in the number of apoptotic cells, the upregulation of pro-apoptotic proteins (Bax, caspase-3 and cytochrome $c$ ) and an increase in $\Delta \Psi \mathrm{m}$. Excessive oxidative stress by products in the mitochondria likely serves as an upstream trigger of the apoptosis cascade (52). Importantly, oxidative stress-induced apoptosis is a final common pathway for progressive heart failure (53). In this study, pre-treatment of the cells with sulforaphane decreased the number of apoptotic cells, downregulated the levels of pro-apoptotic proteins (Bax, caspase-3 and cytochrome c) and decreased $\Delta \Psi \mathrm{m}$.

Since ROS act as key mediators in doxorubicin cardiotoxicity models, antioxidant defense mechanisms are necessary to maintain normal cellular function. The Nrf2-phase II enzyme system functions as one of the most important antioxidant defense mechanisms by upregulating antioxidant response element-related detoxification (17). In the present study, we focused on one important Nrf2-target protein, HO-1, 
A

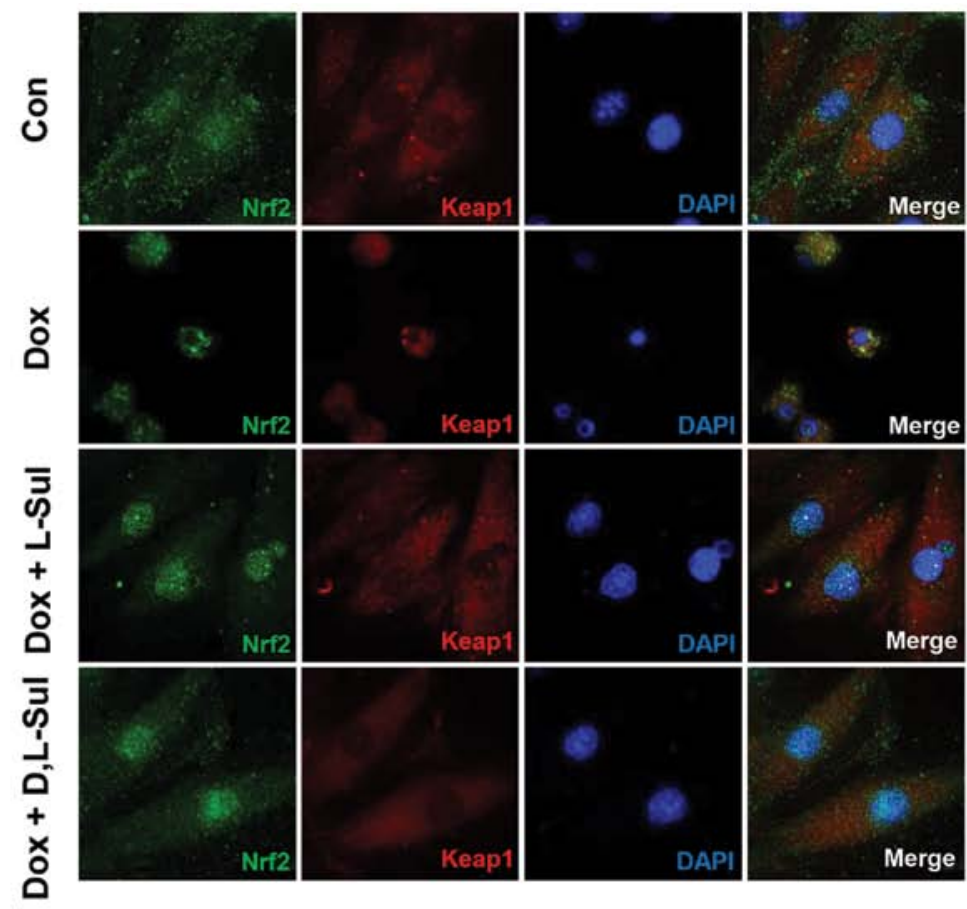

B
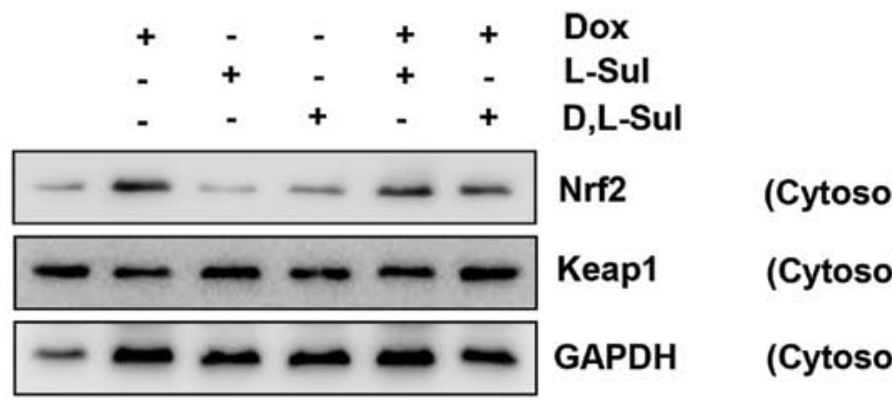

Keap1

(Cytosol)

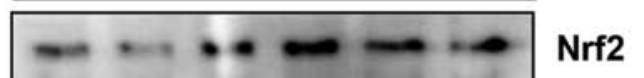

(Cytosol)

GAPDH

(Nuclear)

Histone H3 (Nuclear)

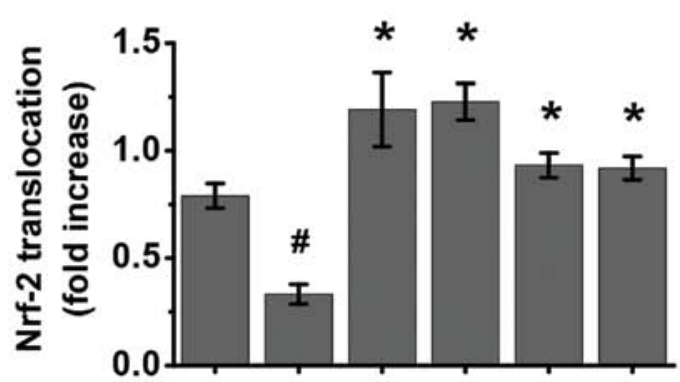

Figure 6. Activation of the Kelch-like ECH-associated protein 1 (Keap1)/NF-E2-related factor-2 (Nrf2) pathway by L-sulforaphane (L-Sul) and D,L-sulforaphane (D,L-Sul) in H9c2 cells. (A) H9c2 cells were treated with $1 \mu \mathrm{M}$ doxorubicin (Dox) or pre-treated with $10 \mu \mathrm{M} \mathrm{L}-\mathrm{Sul}$ or D,L-Sul for $2 \mathrm{~h}$, and then treated with $1 \mu \mathrm{M}$ Dox for $24 \mathrm{~h}$. Cells were double immunostained for Nrf2 and Keap1 and nuclei were visualized by DAPI staining. (B) H9c2 cells were treated with $1 \mu \mathrm{M}$ Dox or pre-treated with $10 \mu \mathrm{M} \mathrm{L}$-Sul or D,L-Sul for $2 \mathrm{~h}$, and then treated with $1 \mu \mathrm{M}$ Dox for $24 \mathrm{~h}$. In parallel, cells were also treated with $10 \mu \mathrm{M} \mathrm{L}-\mathrm{Sul}$ or D,L-Sul alone for $24 \mathrm{~h}$. Nuclear and cytosolic fractions of H9c2 cells were obtained and subjected to western blot analysis using Nrf2 and Keap1 antibodies (top panel). Glyceraldehyde 3-phosphate dehydrogenase (GAPDH) was used as a cytosolic marker, while histone H3 was used to identify nuclear fractions. Densitometric analysis is shown on the lower panel. ${ }^{~} \mathrm{P}<0.05$ vs. controls; ${ }^{*} \mathrm{P}<0.05$ vs. Dox-treated group.

which was increased by pre-treatment with sulforaphane during doxorubicin-induced oxidative stress. Specifically, doxorubicin significantly increased mitochondrial ROS levels, whereas pre-treatment with sulforaphane reversed this increase. The reversal effects of sulforaphane towards the mitochondrial ROS levels confirmed its role as an antioxi- dant in cardiac injury. Although sulforaphane is not a direct antioxidant, it activates the transcription of phase II genes, the products of which provide chemically versatile, often catalytic and prolonged 'indirect' antioxidant protection (54). Although several natural or synthetic compounds may be used to prevent doxorubicin-induced cardiotoxicity $(11,55-59)$, one 
of the major advantages of sulforaphane is that it is already a component of the human diet and is therefore likely to be relatively safe for chronic administration (54). In addition, we observed that L-sulforaphane and D,L-sulforaphane had similar effects. Sulforaphane is one of the promising chemopreventive phytochemicals $(16,60)$. Sulforaphane is able to increase the efficacy of doxorubicin and induce apoptosis in doxorubicin-resistant p53 mutant cells (60). Sulforaphane has been shown to significantly enhance doxorubicin cytoxicity particularly in A549 lung cancer cells, but not in other cancer cells (61). Additional studies are required to further elucidate the mechanisms involved.

In conclusion, the findings of the present study demonstrated that sulforaphane effectively reduced ROS production and apoptosis induced by doxorubicin in $\mathrm{H} 9 \mathrm{c} 2$ cells, and that the protective mechanisms of action of sulforaphane were mediated by preconditioning through the activation of $\mathrm{Nrf} 2$ and the subsequent induction of HO-1. Additional studies are warranted to obtain further insight into the clinical modalities through which sulforaphane exerts its beneficial effects on patients who are at risk of heart injury after receiving doxorubicin chemotherapy by improving heart function. Nevertheless, the dietary consumption of sulforaphane-containing cruciferous vegetables, such as broccoli may prove to be useful in patients to prevent doxorubicin-induced cardiotoxicity.

\section{Acknowledgements}

This study was supported by grants from the National Research Foundation of Korea (2008-0062279, 2015R1A2A1A13001849 and 2012R1A2A2A01045214).

\section{References}

1. Vilaseca J, Guardia J, Bacardi R and Monné J: Doxorubicin for liver cancer. Lancet 1: 1367, 1978.

2. Arcamone F, Cassinelli G, Fantini G, Grein A, Orezzi P, Pol C and Spalla C: Adriamycin, 14-hydroxydaunomycin, a new antitumor antibiotic from $S$. peucetius var. caesius. Biotechnol Bioeng 11: 1101-1110, 1969.

3. Hortobágyi GN: Anthracyclines in the treatment of cancer. An overview. Drugs 54 (Suppl 4): S1-S7, 1997.

4. Gewirtz DA: A critical evaluation of the mechanisms of action proposed for the antitumor effects of the anthracycline antibiotics adriamycin and daunorubicin. Biochem Pharmacol 57: 727-741, 1999.

5. Muggia FM: Clinical efficacy and prospects for use of pegylated liposomal doxorubicin in the treatment of ovarian and breast cancers. Drugs 54 (Suppl 4): S22-S29, 1997.

6. Naito S, Kotoh S, Omoto T, Osada Y, Sagiyama K, Iguchi A, Ariyoshi A, Hiratsuka Y and Kumazawa J; The Kyushu University Urological Oncology Group: Prophylactic intravesical instillation chemotherapy against recurrence after a transurethral resection of superficial bladder cancer: A randomized controlled trial of doxorubicin plus verapamil versus doxorubicin alone. Cancer Chemother Pharmacol 42: 367-372, 1998.

7. Mukhopadhyay P, Rajesh M, Bátkai S, Kashiwaya Y, Haskó G, Liaudet L, Szabó C and Pacher P: Role of superoxide, nitric oxide, and peroxynitrite in doxorubicin-induced cell death in vivo and in vitro. Am J Physiol Heart Circ Physiol 296: H1466-H1483, 2009.

8. Childs AC, Phaneuf SL, Dirks AJ, Phillips T and Leeuwenburgh C: Doxorubicin treatment in vivo causes cytochrome $c$ release and cardiomyocyte apoptosis, as well as increased mitochondrial efficiency, superoxide dismutase activity, and Bcl-2:Bax ratio. Cancer Res 62: 4592-4598, 2002.

9. Tatlidede E, Sehirli O, Velioğlu-Oğünc A, Cetinel S, Yeğen BC, Yarat A, Süleymanoğlu S and Sener G: Resveratrol treatment protects against doxorubicin-induced cardiotoxicity by alleviating oxidative damage. Free Radic Res 43: 195-205, 2009.
10. Wang XL, Wang X, Xiong LL, Zhu Y, Chen HL, Chen JX, Wang XX, Li RL, Guo ZY, Li P and Jiang W: Salidroside improves doxorubicin-induced cardiac dysfunction by suppression of excessive oxidative stress and cardiomyocyte apoptosis. J Cardiovasc Pharmacol 62: 512-523, 2013.

11. Kim DS, Woo ER, Chae SW, Ha KC, Lee GH, Hong ST, Kwon DY, Kim MS, Jung YK, Kim HM, et al: Plantainoside D protects adriamycin-induced apoptosis in $\mathrm{H} 9 \mathrm{c} 2$ cardiac muscle cells via the inhibition of ROS generation and NF-kappaB activation. Life Sci 80: 314-323, 2007.

12. Zhang Y, Talalay P, Cho CG and Posner GH: A major inducer of anticarcinogenic protective enzymes from broccoli: Isolation and elucidation of structure. Proc Natl Acad Sci USA 89: 2399-2403, 1992.

13. Sakao K and Singh SV: D,L-sulforaphane-induced apoptosis in human breast cancer cells is regulated by the adapter protein p66Shc. J Cell Biochem 113: 599-610, 2012.

14. Nestle M: Broccoli sprouts as inducers of carcinogen-detoxifying enzyme systems: Clinical, dietary, and policy implications. Proc Natl Acad Sci USA 94: 11149-11151, 1997.

15. Tanito M, Masutani H, Kim YC, Nishikawa M, Ohira A and Yodoi J: Sulforaphane induces thioredoxin through the antioxidant-responsive element and attenuates retinal light damage in mice. Invest Ophthalmol Vis Sci 46: 979-987, 2005.

16. Surh YJ: Cancer chemoprevention with dietary phytochemicals. Nat Rev Cancer 3: 768-780, 2003.

17. Yoon HY, Kang NI, Lee HK, Jang KY, Park JW and Park BH: Sulforaphane protects kidneys against ischemia-reperfusion injury through induction of the Nrf2-dependent phase 2 enzyme. Biochem Pharmacol 75: 2214-2223, 2008.

18. Zhao J, Kobori N, Aronowski J and Dash PK: Sulforaphane reduces infarct volume following focal cerebral ischemia in rodents. Neurosci Lett 393: 108-112, 2006.

19. Satoh T, Okamoto SI, Cui J, Watanabe Y, Furuta K, Suzuki M, Tohyama K and Lipton SA: Activation of the Keap1/Nrf2 pathway for neuroprotection by electrophilic [correction of electrophillic] phase II inducers. Proc Natl Acad Sci USA 103: 768-773, 2006.

20. Barbagallo I, Galvano F, Frigiola A, Cappello F, Riccioni G, Murabito P, D'Orazio N, Torella M, Gazzolo D and Li Volti G: Potential therapeutic effects of natural heme oxygenase-1 inducers in cardiovascular diseases. Antioxid Redox Signal 18: 507-521, 2013.

21. Jazwa A and Cuadrado A: Targeting heme oxygenase-1 for neuroprotection and neuroinflammation in neurodegenerative diseases. Curr Drug Targets 11: 1517-1531, 2010.

22. Wang RQ, Nan YM, Wu WJ, Kong LB, Han F, Zhao SX, Kong L and $\mathrm{Yu}$ J: Induction of heme oxygenase-1 protects against nutritional fibrosing steatohepatitis in mice. Lipids Health Dis 10: 31 , 2011.

23. Angeloni C, Leoncini E, Malaguti M, Angelini S, Hrelia P and Hrelia S: Modulation of phase II enzymes by sulforaphane: Implications for its cardioprotective potential. J Agric Food Chem 57: 5615-5622, 2009.

24. Piao CS, Gao S, Lee GH, Kim S, Park BH, Chae SW, Chae HJ and Kim SH: Sulforaphane protects ischemic injury of hearts through antioxidant pathway and mitochondrial K(ATP) channels. Pharmacol Res 61: 342-348, 2010.

25. Strober W: Trypan blue exclusion test of cell viability. Curr Protoc Immunol Appendix 3: Appendix 3B, 2001.

26. Latt SA and Wohlleb JC: Optical studies of the interaction of 33258 Hoechst with DNA, chromatin, and metaphase chromosomes. Chromosoma 52: 297-316, 1975.

27. Chae HJ, Kim HR, Xu C, Bailly-Maitre B, Krajewska M, Krajewski S, Banares S, Cui J, Digicaylioglu M, Ke N, et al: BI-1 regulates an apoptosis pathway linked to endoplasmic reticulum stress. Mol Cell 15: 355-366, 2004.

28. Ludke AR, Sharma AK, Akolkar G, Bajpai G and Singal PK: Downregulation of vitamin C transporter SVCT-2 in doxorubicin-induced cardiomyocyte injury. Am J Physiol Cell Physiol 303: C645-C653, 2012.

29. Jiang M, Wang CY, Huang S, Yang T and Dong Z: Cisplatininduced apoptosis in p53-deficient renal cells via the intrinsic mitochondrial pathway. Am J Physiol Renal Physiol 296: F983-F993, 2009.

30. Salvioli S, Ardizzoni A, Franceschi C and Cossarizza A: JC-1, but not DiOC6(3) or rhodamine 123, is a reliable fluorescent probe to assess delta psi changes in intact cells: Implications for studies on mitochondrial functionality during apoptosis. FEBS Lett 411: 77-82, 1997. 
31. Kooy NW, Royall JA, Ischiropoulos H and Beckman JS Peroxynitrite-mediated oxidation of dihydrorhodamine 123. Free Radic Biol Med 16: 149-156, 1994.

32. Tarpey MM and Fridovich I: Methods of detection of vascular reactive species: Nitric oxide, superoxide, hydrogen peroxide, and peroxynitrite. Circ Res 89: 224-236, 2001.

33. Sobreira C, Davidson M, King MP and Miranda AF: Dihydrorhodamine 123 identifies impaired mitochondrial respiratory chain function in cultured cells harboring mitochondrial DNA mutations. J Histochem Cytochem 44: 571-579, 1996.

34. Crow JP: Dichlorodihydrofluorescein and dihydrorhodamine 123 are sensitive indicators of peroxynitrite in vitro: Implications for intracellular measurement of reactive nitrogen and oxygen species. Nitric Oxide 1: 145-157, 1997.

35. Robinson KM, Janes MS and Beckman JS: The selective detection of mitochondrial superoxide by live cell imaging. Nat Protoc 3: 941-947, 2008.

36. Mukhopadhyay P, Rajesh M, Yoshihiro K, Haskó G and Pacher P: Simple quantitative detection of mitochondrial superoxide production in live cells. Biochem Biophys Res Commun 358: 203-208, 2007.

37. Ito T, Okumura H, Tsukue N, Kobayashi T, Honda $\mathrm{K}$ and Sekizawa K: Effect of diesel exhaust particles on mRNA expression of viral and bacterial receptors in rat lung epithelial L2 cells. Toxicol Lett 165: 66-70, 2006.

38. Ly JD, Grubb DR and Lawen A: The mitochondrial membrane potential (deltapsi(m)) in apoptosis; an update. Apoptosis 8: 115-128, 2003.

39. Tsang WP, Chau SP, Kong SK, Fung KP and Kwok TT: Reactive oxygen species mediate doxorubicin induced p53-independent apoptosis. Life Sci 73: 2047-2058, 2003.

40. Sawyer DB, Fukazawa R, Arstall MA and Kelly RA: Daunorubicin-induced apoptosis in rat cardiac myocytes is inhibited by dexrazoxane. Circ Res 84: 257-265, 1999.

41. Kotamraju S, Konorev EA, Joseph J and Kalyanaraman B: Doxorubicin-induced apoptosis in endothelial cells and cardiomyocytes is ameliorated by nitrone spin traps and ebselen. Role of reactive oxygen and nitrogen species. J Biol Chem 275 : 33585-33592, 2000

42. Mihm MJ, Yu F, Weinstein DM, Reiser PJ and Bauer JA: Intracellular distribution of peroxynitrite during doxorubicin cardiomyopathy: Evidence for selective impairment of myofibrillar creatine kinase. Br J Pharmacol 135: 581-588, 2002.

43. Luanpitpong $\mathrm{S}$, Chanvorachote $\mathrm{P}$, Nimmannit U, Leonard SS, Stehlik C, Wang L and Rojanasakul Y: Mitochondrial superoxide mediates doxorubicin-induced keratinocyte apoptosis through oxidative modification of ERK and Bcl-2 ubiquitination. Biochem Pharmacol 83: 1643-1654, 2012.

44. Lee YJ, Jeong HY, Kim YB, Lee YJ, Won SY, Shim JH, Cho MK, Nam HS and Lee SH: Reactive oxygen species and PI3K/Akt signaling play key roles in the induction of Nrf2-driven heme oxygenase-1 expression in sulforaphane-treated human mesothelioma MSTO-211H cells. Food Chem Toxicol 50: 116-123, 2012

45. Surh YJ, Na HK and Lee SS: Transcription factors and mitogenactivated protein kinases as molecular targets for chemoprevention with anti-inflammatory phytochemicals. Biofactors 21: 103-108, 2004.

46. Scott JM, Khakoo A, Mackey JR, Haykowsky MJ, Douglas PS and Jones LW: Modulation of anthracycline-induced cardiotoxicity by aerobic exercise in breast cancer: Current evidence and underlying mechanisms. Circulation 124: 642-650, 2011.
47. Kimes BW and Brandt BL: Properties of a clonal muscle cell line from rat heart. Exp Cell Res 98: 367-381, 1976.

48. Watkins SJ, Borthwick GM and Arthur HM: The H9C2 cell line and primary neonatal cardiomyocyte cells show similar hypertrophic responses in vitro. In Vitro Cell Dev Biol Anim 47: 125-131, 2011.

49. Prathapan A, Vineetha VP, Abhilash PA and Raghu KG: Boerhaavia diffusa L. attenuates angiotensin II-induced hypertrophy in $\mathrm{H} 9 \mathrm{c} 2$ cardiac myoblast cells via modulating oxidative stress and down-regulating NF- $\mathrm{B}$ and transforming growth factor $\beta 1$. Br J Nutr 110: 1201-1210, 2013.

50. Karagiannis TC, Lin AJ, Ververis K, Chang L, Tang MM, Okabe J and El-Osta A: Trichostatin A accentuates doxorubicininduced hypertrophy in cardiac myocytes. Aging (Albany NY) 2: 659-668, 2010.

51. Merten KE, Jiang Y, Feng W and Kang YJ: Calcineurin activation is not necessary for Doxorubicin-induced hypertrophy in $\mathrm{H} 9 \mathrm{c} 2$ embryonic rat cardiac cells: Involvement of the phosphoinositide 3-kinase-Akt pathway. J Pharmacol Exp Ther 319: 934-940, 2006.

52. Wang GW, Klein JB and Kang YJ: Metallothionein inhibits doxorubicin-induced mitochondrial cytochrome $c$ release and caspase-3 activation in cardiomyocytes. J Pharmacol Exp Ther 298: 461-468, 2001.

53. Hare JM: Oxidative stress and apoptosis in heart failure progression. Circ Res 89: 198-200, 2001.

54. Gao X and Talalay P: Induction of phase 2 genes by sulforaphane protects retinal pigment epithelial cells against photooxidative damage. Proc Natl Acad Sci USA 101: 10446-10451, 2004.

55. Al-Abd AM, Al-Abbasi FA, Asaad GF and Abdel-Naim AB: Didox potentiates the cytotoxic profile of doxorubicin and protects from its cardiotoxicity. Eur J Pharmacol 718: 361-369, 2013.

56. Jay SM, Murthy AC, Hawkins JF, Wortzel JR, Steinhauser ML, Alvarez LM, Gannon J, Macrae CA, Griffith LG and Lee RT: An engineered bivalent neuregulin protects against doxorubicininduced cardiotoxicity with reduced proneoplastic potential. Circulation 128: 152-161, 2013.

57. Osman AM, Al-Harthi SE, AlArabi OM, Elshal MF, Ramadan WS, Alaama MN, Al-Kreathy HM, Damanhouri ZA and Osman OH: Chemosensetizing and cardioprotective effects of resveratrol in doxorubicin- treated animals. Cancer Cell Int 13: 52, 2013.

58. Ahmed LA and El-Maraghy SA: Nicorandil ameliorates mitochondrial dysfunction in doxorubicin-induced heart failure in rats: Possible mechanism of cardioprotection. Biochem Pharmacol 86: 1301-1310, 2013.

59. Choi HJ, Seon MR, Lim SS, Kim JS, Chun HS and Park JH: Hexane/ethanol extract of Glycyrrhiza uralensis licorice suppresses doxorubicin-induced apoptosis in $\mathrm{H} 9 \mathrm{c} 2$ rat cardiac myoblasts. Exp Biol Med (Maywood) 233: 1554-1560, 2008.

60. Fimognari C, Nüsse M, Lenzi M, Sciuscio D, Cantelli-Forti G and Hrelia P: Sulforaphane increases the efficacy of doxorubicin in mouse fibroblasts characterized by p53 mutations. Mutat Res 601: 92-101, 2006.

61. Hu L, Miao W, Loignon M, Kandouz M and Batist G: Putative chemopreventive molecules can increase Nrf2-regulated cell defense in some human cancer cell lines, resulting in resistance to common cytotoxic therapies. Cancer Chemother Pharmacol 66: 467-474, 2010. 